\title{
Gene array of PDL cells exposed to Osteogain in combination with a bone grafting material
}

\author{
Richard J. Miron ${ }^{1,2,3} \cdot$ Yuang Shuang ${ }^{4} \cdot$ Anton Sculean $^{2} \cdot$ Daniel Buser $^{3}$ • \\ Fatiha Chandad $^{1}$ - Yufeng Zhang ${ }^{4}$
}

Received: 18 May 2015 / Accepted: 28 December 2015 / Published online: 8 January 2016

(C) Springer-Verlag Berlin Heidelberg 2016

\begin{abstract}
Objectives The aim of the present study was to investigate the effects of Osteogain, a new formulation of enamel matrix derivative (EMD) in combination with a grafting material on a wide variety of genes for cytokines, transcription factors and extracellular matrix proteins involved in osteoblast differentiation.

Materials and methods Primary human periodontal ligament (PDL) cells were seeded on natural bone mineral (NBM) particles coated with Osteogain for $24 \mathrm{~h}$ and analyzed for regulated gene expression using a human osteogenesis gene superarray kit. Osteoblast-related genes include those transcribed during bone mineralization, ossification, bone metabolism, cell growth and differentiation as well as gene products representing extracellular matrix molecules, transcription factors and cell adhesion molecules.
\end{abstract}

Richard J. Miron

richard.miron@zmk.unibe.ch

Yufeng Zhang

zyf@whu.edu.cn

1 Faculté de Médecine Dentaire, Pavillon de Médecine Dentaire, Université Laval, Rue de la Terrasse, Québec, Canada

2 Department of Periodontology, School of Dental Medicine, University of Bern, Freiburgstrasse 7, 3010 Bern, Switzerland

3 Department of Oral Surgery and Stomatology, School of Dental Medicine, University of Bern, Freiburgstrasse 7, 3010 Bern, Switzerland

4 The State Key Laboratory Breeding Base of Basic Science of Stomatology (Hubei-MOST) and Key Laboratory of Oral Biomedicine Ministry of Education, School and Hospital of Stomatology, Wuhan University, 237 Luoyu Road, Wuhan 430079, People's Republic of China
Results Osteogain significantly upregulated the expression of over 20 of the 100 genes examined including bone morphogenetic protein 2 (BMP2), TGF $\beta 1$, fibroblast growth factor (FGF), epidermal growth factor (EGF) and platelet-derived growth factor (PDGF) as well as some of their associated receptors. Osteogain also promoted gene expression of a number of osteoblast differentiation markers including collagen $1 \alpha 2$ and alkaline phosphatase as well as cell adhesion molecules including fibronectin and a variety of integrin binding proteins. Interestingly, Osteogain promoted calcitonin receptor 55-fold and also promoted annexin A5 gene expression over 12-fold.

Conclusion The present study demonstrates that Osteogain is capable of either upregulating or downregulating the expression of a wide variety of genes including those for growth factors and cytokines when combined with a bone grafting material.

Clinical relevance The results from the present study demonstrate the large and potent effect of addition of Osteogain in combination to a bone grafting material over a wide variety of genes supporting osteogenesis.

Keywords Enamel matrix derivative $\cdot$ Enamel matrix proteins $\cdot$ Emdogain $\cdot$ Periodontal regeneration $\cdot$ Bone graft

\section{Introduction}

Enamel matrix derivative (EMD) has been shown to promote periodontal regeneration by inducing new root cementum, periodontal ligament and alveolar bone formation as well as to speed up tissue wound healing [1-4]. The major components of EMD are amelogenins, a family of hydrophobic proteins that account for more than $95 \%$ of the total protein content [5]. These proteins self-assemble into supramolecular 
aggregates that form an insoluble extracellular matrix that function to control the ultrastructural organization of the developing enamel crystallites [5]. Other proteins found in the enamel matrix include enamelin, ameloblastin (also called amelin or sheathlin), amelotin, apin and various proteinases $[6,7]$. The rationale for the clinical use of EMD is the observation that enamel matrix proteins (EMPs) are deposited onto the surface of developing tooth roots prior to cementum formation [8].

Although histological studies in animals and humans have provided evidence for periodontal regeneration and substantial clinical improvements following the use of EMD (commercially available under the trademark name Emdogain; Straumann AG, Basel, Switzerland), concerns have been expressed regarding the viscous nature of Emdogain gel, which may not be sufficient to prevent flap collapse in periodontal defects with a complicated anatomy $[9,10]$. In order to overcome this potential limitation and improve the clinical outcomes, various combinations of Emdogain and different types of grafting materials have been used [1]. The combination of Emdogain with a natural bone mineral (NBM) of bovine origin has provided increased periodontal regeneration power and substantial clinical improvements when compared to either NBM alone or Emdogain alone [1]. Recently, a new carrier system for enamel matrix derivative was designed to improve protein adsorption of enamel matrix proteins to grafting materials [11-13]. In a pioneering study, it was found that more proteins are adsorbed on the material surface when EMD was delivered in liquid formulation when compared to the gel formulation found in Emdogain [11]. Advantages also included better surface coating of the protein and penetration of EMPs within the bone grafting material surface [11]. Following preliminary experiments, a new carrier system was developed in liquid formulation for EMD (Osteogain; Straumann AG). The aim of the present study was therefore to investigate the effects of Osteogain in combination with NBM on the initial periodontal ligament (PDL) cell behaviour when compared to NBM alone by assessing the gene expression of a wide variety of osteoblast cytokines, growth factors, differentiation markers and extracellular matrix molecules using a commercially available super-array kit.

\section{Methods}

\section{Osteogain and bone grafting material}

For all in vitro experiments, Osteogain (0.3-ml vials, working concentration $30 \mathrm{mg} / \mathrm{ml}$ ) was kindly provided by Straumann AG, Malmo, Sweden. In order to reach the in vitro working concentration of $100 \mu \mathrm{g} / \mathrm{ml}$, Osteogain was diluted in cell culture media containing $10 \%$ FBS. For all in vitro cell experiments, cells were exposed to culture media containing
Osteogain at time point 0 until the end of the experiment. A NBM bone grafting material (Bio-Oss, Geistlich, Switzerland) was utilized as the material of choice for the present study due to our laboratories previously handling its use as well as its ability to adsorb enamel matrix proteins within the material graft [11].

\section{PDL cell isolation and differentiation}

Primary human PDL cells were isolated from the middle third of extracted premolars for orthodontic reasons from patients demonstrating no signs of periodontal disease as previously described $[14,15]$. Informed consent was obtained from all the participants. Primary PDL cells were detached from the tissue culture plastic using trypsin solution. Cells used for experimental seeding were from passages 4-6. Primary PDL cells were seeded at a density of 500,000 cells on top of $500 \mathrm{mg}$ NBM material per well in 6-well dishes for superarray analysis. Assays were performed in quadruplicates with four independent experiments performed from four different human donors.

\section{Super-array of osteogenic potential}

The initial expression of osteoblast-related genes was examined after culture of cells for $24 \mathrm{~h}$. Total RNA was isolated using TRIzol reagent and RNeasy Mini Kit (QIAGEN, Basel, Switzerland). A TaqMan ${ }^{\circledR}$ Human Osteogenesis 96-well Plate Super-array (4414096; Applied Biosystems, Rotkreuz, Switzerland) was employed for the analysis. Osteoblast-related genes include those transcribed during bone mineralization, ossification, bone metabolism, cell growth and differentiation. The gene products represent extracellular matrix molecules, transcription factors and cell adhesion molecules among others. Real-time RT-PCR was performed according to the manufacturer's protocol using the $20 \mu \mathrm{l}$ final reaction volume of TaqMan ${ }^{\circledR}$ One-Step Master Mix Kit (Applied Biosystems) as previously described [16]. RNA quantification was performed using a NanoDrop 2000c (Thermo Scientific, Waltham, MA, USA), and $100 \mathrm{ng}$ of the total RNA was used per sample well. A gene fold increase represents data from cells grown in the presence of NBM particles precoated or not with Osteogain.

\section{Statistical analysis}

Gene array analysis was performed for both $\operatorname{control}(n=4)$ and Osteogain $(n=4)$ groups. Means and standard deviations (SDs) were calculated, and the statistically significant differences were examined by Student's $t$ test between both groups ( ${ }^{*} p$ values $<0.05$ was considered significant). 


\section{Results}

The full set of genes investigated in the present study is listed in Table 1 in alphabetical order. As depicted, a number of genes involved in osteogenesis were upregulated with the vast majority between 1- and 10-fold when cells were cultured in the presence of Osteogain (Table 1). For the purpose of this experiment, only genes having been upregulated over 3 -fold or those that demonstrated a significance of greater than a $p$ value of 0.05 are discussed. Alpha-2-HS-glycoprotein was upregulated 5.09-fold with a $p$ value of 0.002. Alkaline phosphatase and annexin 5 were upregulated $[3.19(p=0.022)$ and $12.08(p=0.001)$, respectively]. From the number of tested bone morphogenetic proteins (BMPs), bone morphogenetic protein 2 (BMP2) showed the highest upregulation of 6.96 $(p=0.039)$ with its associated receptor upregulated 3.09-fold when compared to control cells seeded on NBM alone. Interestingly, the addition of Osteogain upregulated calcitonin receptor 55.95-fold $(p=0.008)$. Both epidermal growth factor (EGF) and fibroblast growth factor (FGF) demonstrated increased expression with their associated receptors being upregulated also (Table 1). Fibronectin, a cell attachment protein, was upregulated 3.4-fold $(p=0.018)$. A number of integrin binding proteins were upregulated between 2.6- and 9.04-fold (Table 1). Platelet-derived growth factor (PDGF) was upregulated 1.74-fold; however, this demonstrated statistically significant differences from control $(p=0.019)$. SMAD1 and SMAD2, members of intracellular pathways for BMPs, were significantly upregulated 1.89- and 2.62-fold $(p<0.05)$. Lastly, both Twist homolog 1 and vitamin $\mathrm{D}$ were both upregulated 2.66- and 5.58-fold, respectively, with both demonstrating significant differences from controls $(p=0.025$ and $p=0.047$, respectively).

\section{Discussion}

The aim of the present study was to investigate the role of Osteogain when combined with bone grafting materials in comparison to NBM alone on a wide array of genes related to osteogenesis. As such, the use of a gene array with a predesigned set of roughly 100 genes was utilized in order to determine possible mechanisms/roles of enamel matrix proteins on osteoblast differentiation. Interestingly, of the 100 genes investigated, 21 genes demonstrated either a 3-fold upregulation or a $p<0.05$ when compared to control samples (Table 1). Many of these genes were upregulated between 2and 10 -fold.

One of the surprising results from this study was that calcitonin receptor was upregulated over 55 -fold following the addition of Osteogain to a bone grafting material. Calcitonin has several roles in the body. More specifically, it is responsible for lowering blood $\mathrm{Ca}^{2+}$ primarily by inhibiting osteoclast activity and stimulating osteoblast activity [17]. Furthermore, what is impressive about these results is that we used different primary PDL cells from four different human donors. Thus, this significant upregulation is independent of slight human variations and it seems plausible that Osteogain may have some effect and/or some regulation through calcitonin/ calcitonin receptors. Furthermore, a second gene for which was most significantly upregulated was annexin A5 with a 12.08-fold increase when treated with Osteogain. Annexin A5 is a calcium-dependent phospholipid binding protein which has been suggested to play a role as a mechanosensitive ion channel [18]. Disruption of its expression impairs mechanically induced calcium signalling in osteoblasts, and it has the ability to interact with both extracellular matrix proteins and cytoskeletal elements [18]. Thus, the pairing of upregulated genes calcitonin receptor and annexin A5 suggests a possible role of calcium regulation via enamel matrix proteins. Further investigations in this area are necessary.

The use of Osteogain also elicited a significant upregulation of many growth factors and their associated receptors (Table 1). Of the group of BMPs, BMP2 was the most upregulated with a significant increase of 6.96-fold when treated with Osteogain + NBM in comparison to NBM alone (Table 1). Furthermore, both bone morphogenetic protein receptor 2 and intracellular protein SMAD2 were upregulated 3.07- and 2.69 -fold, respectively. Thus, the present study reveals that enamel matrix proteins have a significant influence on the $\mathrm{BMP} /$ cell signalling events that take place following cell culture with Osteogain. This is in accordance with previous publications that have demonstrated this phenomenon [19-21]. The family of SMAD signal proteins are found in many cell types and are responsible for transducing extracellular signals from TGF $\beta$ and BMPs from the cell membrane to the nucleus [22]. Kawase et al. showed in two consecutive studies that EMD was able to induce rapid translocation of SMAD2 to the nucleus and this was responsible for increased cell proliferation $[23,24]$. In the present study, we also observed a significant increase of SMAD2 by 2.69 -fold in as short as $24 \mathrm{~h}$ following exposure to Osteogain (Table 1).

Apart from BMP signalling, it was also found that gene expressions of TGF $\beta 1$, PDGF, EGF and FGF were all upregulated in response to Osteogain (Table 1). Furthermore, the associated receptors of both EGF and FGF were also upregulated. This is in accordance with our previously published gene array which has demonstrated the large effects of EMD on many growth factors, cytokines and their associated receptors [20]. Thus, this study further confirms the effects of Osteogain as opposed to gel-like substance Emdogain and demonstrates its ability to elicit a large effect on gene expression from primary human PDL cells.

Interestingly, Osteogain was also able to have effects on cell adhesion molecules including fibronectin and various integrin binding proteins (Table 1). Fibronectin is a known 
Table 1 Osteogenic gene array of primary PDL cells exposed to Osteogain in combination with NBM bone graft in comparison to NBM alone

\begin{tabular}{|c|c|c|c|c|c|}
\hline \multirow[t]{2}{*}{ Symbol } & \multirow[t]{2}{*}{ Name } & \multicolumn{2}{|c|}{ AVG $\Delta \mathrm{C}_{\mathrm{t}}(\mathrm{Ct}(\mathrm{GOI})-\operatorname{Ave} \mathrm{Ct}(\mathrm{HKG}))$} & \multirow{2}{*}{$\begin{array}{l}\text { Fold change } \\
\text { Test sample/ } \\
\text { control sample }\end{array}$} & \multirow{2}{*}{$\begin{array}{l}t \text { test } \\
p \text { value }\end{array}$} \\
\hline & & $\begin{array}{l}\text { Test } \\
\text { sample }\end{array}$ & $\begin{array}{l}\text { Control } \\
\text { sample }\end{array}$ & & \\
\hline ACVR1 & Activin A receptor, type I & -7.80 & -7.47 & 1.25 & 0.915332 \\
\hline AHSG & Alpha-2-HS-glycoprotein & -11.85 & -9.51 & 5.09 & 0.001627 \\
\hline ALPL & Alkaline phosphatase, liver/bone/kidney & -9.80 & -8.13 & 3.19 & 0.021668 \\
\hline ANXA5 & Annexin A5 & -9.36 & -5.76 & 12.08 & 0.000579 \\
\hline BGLAP & Bone gamma-carboxyglutamate (gla) protein & -2.41 & -2.82 & 0.75 & 0.620107 \\
\hline BGN & Biglycan & -6.86 & -7.30 & 0.74 & 0.596608 \\
\hline BMP1 & Bone morphogenetic protein 1 & -3.08 & -4.07 & 0.51 & 0.247237 \\
\hline BMP2 & Bone morphogenetic protein 2 & -7.12 & -4.32 & 6.96 & 0.038526 \\
\hline BMP3 & Bone morphogenetic protein 3 & -3.56 & -3.48 & 1.06 & 0.596056 \\
\hline BMP4 & Bone morphogenetic protein 4 & -4.00 & -3.61 & 1.31 & 0.228776 \\
\hline BMP5 & Bone morphogenetic protein 5 & -9.34 & -9.17 & 1.13 & 0.673938 \\
\hline BMP6 & Bone morphogenetic protein 6 & -10.05 & -9.89 & 1.11 & 0.734613 \\
\hline BMP7 & Bone morphogenetic protein 7 & -3.29 & -2.29 & 1.99 & 0.202071 \\
\hline BMPR1A & Bone morphogenetic protein receptor, type IA & -3.60 & -3.87 & 0.83 & 0.942792 \\
\hline BMPR1B & Bone morphogenetic protein receptor, type IB & -12.16 & -10.98 & 2.27 & 0.208567 \\
\hline BMPR2 & $\begin{array}{l}\text { Bone morphogenetic protein receptor, type II } \\
\text { (serine/threonine kinase) }\end{array}$ & -4.80 & -3.18 & 3.07 & 0.145458 \\
\hline CALCR & Calcitonin receptor & -9.28 & -3.47 & 55.95 & 0.007783 \\
\hline CD36 & CD36 molecule (thrombospondin receptor) & -3.90 & -4.72 & 0.56 & 0.439813 \\
\hline CDH11 & Cadherin 11, type 2, OB-cadherin (osteoblast) & -6.06 & -6.89 & 0.56 & 0.778036 \\
\hline CHRD & Chordin & -11.23 & -11.17 & 1.04 & 0.343664 \\
\hline COL10A1 & Collagen, type X, alpha 1 & -12.43 & -11.34 & 2.13 & 0.460268 \\
\hline COL14A1 & Collagen, type XIV, alpha 1 & -7.23 & -5.96 & 2.42 & 0.463013 \\
\hline COL15A1 & Collagen, type XV, alpha 1 & -7.84 & -6.37 & 2.76 & 0.337634 \\
\hline COL1A1 & Collagen, type I, alpha 1 & -5.50 & -5.52 & 0.99 & 0.977061 \\
\hline COL1A2 & Collagen, type I, alpha 2 & -12.75 & -11.14 & 3.06 & 0.822122 \\
\hline COL2A1 & Collagen, type II, alpha 1 & -6.53 & -7.49 & 0.51 & 0.072133 \\
\hline COL3A1 & Collagen, type III, alpha 1 & -3.59 & -3.73 & 0.91 & 0.793750 \\
\hline COL5A1 & Collagen, type $\mathrm{V}$, alpha 1 & -2.21 & -3.36 & 0.45 & 0.243179 \\
\hline COMP & Cartilage oligomeric matrix protein & -13.01 & -13.39 & 0.77 & 0.273670 \\
\hline CSF1 & Colony-stimulating factor 1 (macrophage) & -9.87 & -8.68 & 2.27 & 0.325348 \\
\hline CSF2 & Colony-stimulating factor 2 (granulocyte-macrophage) & -1.68 & -1.71 & 0.98 & 0.950459 \\
\hline CSF3 & Colony-stimulating factor 3 (granulocyte) & -5.76 & -6.45 & 0.62 & 0.630748 \\
\hline CTSK & Cathepsin K & -5.41 & -5.97 & 0.68 & 0.649570 \\
\hline DLX5 & Distal-less homeobox 5 & -9.36 & -8.41 & 1.93 & 0.425777 \\
\hline EGF & Epidermal growth factor & -13.41 & -11.60 & 3.50 & 0.035436 \\
\hline EGFR & Epidermal growth factor receptor & -11.16 & -8.51 & 6.28 & 0.015134 \\
\hline FGF1 & Fibroblast growth factor 1 (acidic) & -7.57 & -5.38 & 4.58 & 0.040644 \\
\hline FGF2 & Fibroblast growth factor 2 (basic) & -16.41 & -15.07 & 2.54 & 0.002678 \\
\hline FGFR1 & Fibroblast growth factor receptor 1 & -2.73 & -2.74 & 0.99 & 0.928878 \\
\hline FGFR2 & Fibroblast growth factor receptor 2 & -2.98 & -2.08 & 1.87 & 0.031555 \\
\hline FLT1 & $\begin{array}{l}\text { Fms-related tyrosine kinase } 1 \text { (vascular endothelial growth } \\
\text { factor/vascular permeability factor receptor) }\end{array}$ & -6.56 & -7.33 & 0.59 & 0.338385 \\
\hline FN1 & Fibronectin 1 & -8.03 & -6.26 & 3.40 & 0.018460 \\
\hline GDF10 & Growth differentiation factor 10 & -6.67 & -6.01 & 1.58 & 0.489789 \\
\hline GLI1 & GLI family zinc finger 1 & -6.86 & -6.86 & 1.00 & 0.730111 \\
\hline ICAM1 & Intercellular adhesion molecule 1 & -7.58 & -7.61 & 0.98 & 0.596638 \\
\hline
\end{tabular}


Table 1 (continued)

\begin{tabular}{|c|c|c|c|c|c|}
\hline \multirow[t]{2}{*}{ Symbol } & \multirow[t]{2}{*}{ Name } & \multicolumn{2}{|c|}{ AVG $\Delta \mathrm{C}_{\mathrm{t}}(\mathrm{Ct}(\mathrm{GOI})-\operatorname{Ave} \mathrm{Ct}(\mathrm{HKG}))$} & \multirow{2}{*}{$\begin{array}{l}\text { Fold change } \\
\text { Test sample/ } \\
\text { control sample }\end{array}$} & \multirow{2}{*}{$t$ test } \\
\hline & & $\begin{array}{l}\text { Test } \\
\text { sample }\end{array}$ & $\begin{array}{l}\text { Control } \\
\text { sample }\end{array}$ & & \\
\hline IGF1 & Insulin-like growth factor 1 (somatomedin C) & -10.81 & -10.31 & 1.42 & 0.185206 \\
\hline IGF1R & Insulin-like growth factor 1 receptor & -6.53 & -6.48 & 1.03 & 0.968599 \\
\hline IGF2 & Insulin-like growth factor 2 (somatomedin A) & -3.10 & -3.69 & 0.66 & 0.553169 \\
\hline $\mathrm{IHH}$ & Indian hedgehog & 1.59 & 1.23 & 0.78 & 0.995198 \\
\hline ITGA1 & Integrin, alpha 1 & -13.98 & -12.60 & 2.60 & 0.009439 \\
\hline ITGA2 & Integrin, alpha 2 (CD49B, alpha 2 subunit of VLA-2 receptor) & -9.18 & -6.01 & 9.04 & 0.000284 \\
\hline ITGA3 & $\begin{array}{l}\text { Integrin, alpha } 3 \text { (antigen CD49C, alpha } 3 \text { subunit of } \\
\text { VLA-3 receptor) }\end{array}$ & -13.77 & -12.70 & 2.10 & 0.003393 \\
\hline ITGAM & Integrin, alpha $\mathrm{M}$ (complement component 3 receptor 3 subunit) & -1.79 & -2.06 & 0.83 & 0.544331 \\
\hline ITGB1 & $\begin{array}{l}\text { Integrin, beta } 1 \text { (fibronectin receptor, beta polypeptide, } \\
\text { antigen CD29 } \\
\text { includes MDF2, MSK12) }\end{array}$ & 0.65 & 1.16 & 1.42 & 0.448769 \\
\hline MMP10 & Matrix metallopeptidase 10 (stromelysin 2) & -4.23 & -4.63 & 0.76 & 0.749247 \\
\hline MMP2 & $\begin{array}{l}\text { Matrix metallopeptidase } 2 \text { (gelatinase A, } 72 \mathrm{kDa} \text { gelatinase, } \\
72 \mathrm{kDa} \text { type IV collagenase) }\end{array}$ & -4.92 & -4.88 & 1.02 & 0.820871 \\
\hline MMP8 & Matrix metallopeptidase 8 (neutrophil collagenase) & -5.12 & -5.51 & 0.77 & 0.619721 \\
\hline MMP9 & $\begin{array}{l}\text { Matrix metallopeptidase } 9 \text { (gelatinase B, } 92 \mathrm{kDa} \text { gelatinase, } \\
92 \mathrm{kDa} \text { type IV collagenase) }\end{array}$ & -6.82 & -6.59 & 1.17 & 0.504086 \\
\hline NFKB1 & $\begin{array}{l}\text { Nuclear factor of kappa light polypeptide gene enhancer in } \\
\text { B cells } 1\end{array}$ & -7.03 & -6.10 & 1.90 & 0.243775 \\
\hline NOG & Noggin & -4.77 & -4.42 & 1.28 & 0.632229 \\
\hline PDGFA & Platelet-derived growth factor alpha polypeptide & -8.05 & -7.26 & 1.74 & 0.018625 \\
\hline PHEX & Phosphate-regulating endopeptidase homolog, $\mathrm{X}$ linked & -9.62 & -9.33 & 1.22 & 0.223625 \\
\hline RUNX2 & Runt-related transcription factor 2 & -5.28 & -5.53 & 0.84 & 0.571962 \\
\hline SERPINH1 & $\begin{array}{l}\text { Serpin peptidase inhibitor, clade } \mathrm{H} \text { (heat shock protein } 47 \text { ), } \\
\text { member } 1 \text { (collagen binding protein } 1 \text { ) }\end{array}$ & -9.13 & -8.93 & 1.15 & 0.418260 \\
\hline SMAD1 & SMAD family member 1 & -9.10 & -8.18 & 1.89 & 0.019281 \\
\hline SMAD2 & SMAD family member 2 & -7.81 & -6.42 & 2.62 & 0.009082 \\
\hline SMAD3 & SMAD family member 3 & -5.55 & -4.31 & 2.36 & 0.514189 \\
\hline SMAD4 & SMAD family member 4 & -4.79 & -3.93 & 1.81 & 0.250318 \\
\hline SMAD5 & SMAD family member 5 & -4.42 & -4.56 & 0.91 & 0.732234 \\
\hline SOX9 & SRY (sex-determining region Y)-box 9 & -5.49 & -5.53 & 0.97 & 0.382991 \\
\hline SP7 & Sp7 transcription factor & -11.41 & -10.75 & 1.58 & 0.338706 \\
\hline SPP1 & Secreted phosphoprotein 1 & -11.44 & -10.56 & 1.85 & 0.593599 \\
\hline TGFB1 & Transforming growth factor, beta 1 & -10.76 & -9.47 & 2.45 & 0.214655 \\
\hline TGFB2 & Transforming growth factor, beta 2 & -1.49 & -2.79 & 0.41 & 0.039454 \\
\hline TGFB3 & Transforming growth factor, beta 3 & -2.73 & -2.86 & 0.92 & 0.884488 \\
\hline TGFBR1 & Transforming growth factor, beta receptor 1 & -6.57 & -7.15 & 0.67 & 0.076319 \\
\hline TGFBR2 & Transforming growth factor, beta receptor II $(70 / 80 \mathrm{kDa})$ & -5.44 & -7.79 & 0.20 & 0.171507 \\
\hline TNF & Tumour necrosis factor & -9.49 & -8.05 & 2.71 & 0.278587 \\
\hline TNFSF11 & Tumour necrosis factor (ligand) superfamily, member 11 & -9.43 & -7.98 & 2.72 & 0.235600 \\
\hline TWIST1 & Twist homolog 1 (Drosophila) & -12.02 & -10.61 & 2.66 & 0.024769 \\
\hline VCAM1 & Vascular cell adhesion molecule 1 & -10.06 & -9.62 & 1.36 & 0.635539 \\
\hline VDR & Vitamin $\mathrm{D}\left(1,25\right.$-dihydroxyvitamin $\left.\mathrm{D}_{3}\right)$ receptor & -9.13 & -6.65 & 5.58 & 0.046791 \\
\hline VEGFA & Vascular endothelial growth factor A & -6.57 & -5.97 & 1.51 & 0.452665 \\
\hline VEGFB & Vascular endothelial growth factor B & -7.84 & -7.62 & 1.17 & 0.419889 \\
\hline
\end{tabular}

Italicized values represent significant difference between NBM+Osteogain group versus NBM alone $(p<0.05)$ 
extracellular matrix protein secreted by various cell types able to increase cell attachment $[25,26]$. Furthermore, the effects of integrin binding have a long history of well-documented effects on cell attachment $[27,28]$. Previous investigation on the attachment of human periodontal ligament cells to enamel matrix-derived protein demonstrated that it is mediated via an interaction between BSP-like molecules and integrin $\alpha v \beta 3$ [29]. Furthermore, other investigators demonstrated that both PDL and gingival fibroblasts showed increased expression of the integrin subunits $\alpha_{2}, \alpha_{5}$ and $\beta_{1}$ and integrin $\alpha_{v} \beta_{3}$ following cell seeding with enamel matrix derivative.

It must be noted that in the present study, the control of utilizing Osteogain alone was not evaluated purely to simulate a clinical setting. Osteogain was developed as a new liquid carrier system for EMD in order to maximize better adsorption of enamel matrix proteins onto a bone grafting material surface. Clinically, the combination approach is often utilized due to the principal reason that Emdogain gel alone is unable to prevent a flap collapse for large intrabony defects, thus necessitating the combination with a bone grafting material. Clinically, it is also possible to use a bone grafting material alone for the treatment of large intrabony defects; thus, it was chosen as a control in the present study. However, the use of Osteogain alone would never be utilized clinically as the liquid formulation of the material would have handling issues. For these reasons, Osteogain alone was not used as a secondary control. Future investigation following the results from the present study will determine the effects of Osteogain on cell behaviour at later time points on specific gene transcription of osteoblast differentiation markers as well as at the protein level.

\section{Conclusion}

The present study demonstrates the potent effects of Osteogain when combined with a bone grafting material on gene expression of many cytokines, growth factors, adhesion molecules and intracellular signalling proteins. It was found that Osteogain was able to significantly upregulate BMP2, TGF $\beta 1$, FGF, EGF and PDGF as well as some of their associated receptors. Osteogain also promoted a number of osteoblast differentiation markers including collagen $1 \alpha 2$ and alkaline phosphatase as well as cell adhesion molecules including fibronectin and a variety of integrin binding proteins. Further research analyzing protein quantification and later time points are now necessary to further investigate the role of Osteogain on new bone formation.

\section{Compliance with ethical standards}

Conflict of interest The authors declare that they have no competing interests.
Funding This work was partially funded by the Institut Straumann AG who also supplied Osteogain for this study.

Ethical approval This article does not contain any studies with human participants or animals performed by any of the authors. For this type of study, formal consent was not required.

Informed consent Informed consent was obtained for cells utilized in this study.

\section{References}

1. Sculean A, Alessandri R, Miron RJ, Salvi G, Bosshard DD (2011) Enamel matrix proteins and periodontal wound healing and regeneration. Clin Adv Periodontics 1:101-117

2. Gkranias ND, Graziani F, Sculean A, Donos N (2012) Wound healing following regenerative procedures in furcation degree III defects: histomorphometric outcomes. Clin Oral Investig 16:239 49. doi:10.1007/s00784-010-0478-7

3. Pietruska M, Pietruski J, Nagy K, Brecx M, Arweiler NB and Sculean A (2011) Four-year results following treatment of intrabony periodontal defects with an enamel matrix derivative alone or combined with a biphasic calcium phosphate. Clin Oral Investig. doi: 10.1007/s00784-011-0611-2

4. Miron RJ, Dard M and Weinreb M (2014) Enamel matrix derivative, inflammation and soft tissue wound healing. Journal of Periodontal Research. doi: 10.1111/jre.12245

5. Lyngstadaas SP, Wohlfahrt JC, Brookes SJ, Paine ML, Snead ML, Reseland JE (2009) Enamel matrix proteins; old molecules for new applications. Orthod Craniofac Res 12:243-53. doi:10.1111/j.16016343.2009.01459.x

6. Margolis HC, Beniash E, Fowler CE (2006) Role of macromolecular assembly of enamel matrix proteins in enamel formation. $\mathrm{J}$ Dent Res 85:775-93

7. Bartlett JD, Ganss B, Goldberg M, Moradian-Oldak J, Paine ML, Snead ML, Wen X, White SN, Zhou YL (2006) 3. Protein-protein interactions of the developing enamel matrix. Curr Top Dev Biol 74:57-115. doi:10.1016/s0070-2153(06)74003-0

8. Hammarstrom L (1997) Enamel matrix, cementum development and regeneration. J Clin Periodontol 24:658-68

9. Polimeni G, Koo KT, Qahash M, Xiropaidis AV, Albandar JM, Wikesjo UM (2004) Prognostic factors for alveolar regeneration: effect of a space-providing biomaterial on guided tissue regeneration. J Clin Periodontol 31:725-9. doi:10.1111/j.1600-051X.2004. 00542.x

10. Siciliano VI, Andreuccetti G, Siciliano AI, Blasi A, Sculean A, Salvi GE (2011) Clinical outcomes after treatment of noncontained intrabony defects with enamel matrix derivative or guided tissue regeneration: a 12-month randomized controlled clinical trial. J Periodontol 82:62-71. doi:10.1902/jop.2010.100144

11. Miron RJ, Bosshardt DD, Buser D, Zhang Y, Tugulu S, Gemperli A, Dard M, Caluseru OM, Chandad F and Sculean A (2015) Comparison of the capacity of enamel matrix derivative-gel and enamel matrix derivative in liquid formulation to adsorb to bone grafting materials. Journal of Periodontology: 1-18. doi: 10.1902/ jop.2015.140538

12. Miron RJ, Chandad F, Buser D, Sculean A, Cochran DL and Zhang Y (2015) Effect of enamel matrix derivative (EMD)-liquid on osteoblast and periodontal ligament cell proliferation and differentiation. Journal of Periodontology: 1-14. doi: 10.1902/jop.2015. 150389 
13. Zhang Y, Jing D, Buser D, Sculean A, Chandad F and Miron RJ (2015) Bone grafting material in combination with Osteogain for bone repair: a rat histomorphometric study. Clinical Oral Investigations. doi: 10.1007/s00784-015-1532-2

14. Miron RJ, Bosshardt DD, Laugisch O, Katsaros C, Buser D, Sculean A (2012) Enamel matrix protein adsorption to root surfaces in the presence or absence of human blood. J Periodontol 83:88592. doi:10.1902/jop.2011.110404

15. Miron RJ, Bosshardt DD, Gemperli AC, Dard M, Buser D, Gruber R, Sculean A (2014) In vitro characterization of a synthetic calcium phosphate bone graft on periodontal ligament cell and osteoblast behavior and its combination with an enamel matrix derivative. Clin Oral Investig 18:443-51. doi:10.1007/s00784-013-0977-4

16. Miron RJ, Oates CJ, Molenberg A, Dard M, Hamilton DW (2010) The effect of enamel matrix proteins on the spreading, proliferation and differentiation of osteoblasts cultured on titanium surfaces. Biomaterials 31:449-60. doi:10.1016/j.biomaterials.2009.09.075

17. Wallach S, Farley JR, Baylink DJ, Brenner-Gati L (1993) Effects of calcitonin on bone quality and osteoblastic function. Calcif Tissue Int 52:335-9

18. Haut Donahue TL, Genetos DC, Jacobs CR, Donahue HJ, Yellowley CE (2004) Annexin V disruption impairs mechanically induced calcium signaling in osteoblastic cells. Bone 35:656-63. doi:10.1016/j.bone.2004.04.025

19. Miron RJ, Bosshardt DD, Hedbom E, Zhang Y, Haenni B, Buser D, Sculean A (2012) Adsorption of enamel matrix proteins to a bovine-derived bone grafting material and its regulation of cell adhesion, proliferation, and differentiation. J Periodontol 83:93647. doi:10.1902/jop.2011.110480

20. Miron RJ, Bosshardt DD, Zhang Y, Buser D, Sculean A (2013) Gene array of primary human osteoblasts exposed to enamel matrix derivative in combination with a natural bone mineral. Clin Oral Investig 17:405-10. doi:10.1007/s00784-012-0742-0
21. Suzuki S, Nagano T, Yamakoshi Y, Gomi K, Arai T, Fukae M, Katagiri T, Oida S (2005) Enamel matrix derivative gel stimulates signal transduction of BMP and TGF-\{beta\}. J Dent Res 84:510-4

22. Heldin CH, Miyazono K, ten Dijke P (1997) TGF-beta signalling from cell membrane to nucleus through SMAD proteins. Nature 390:465-71. doi:10.1038/37284

23. Kawase T, Okuda K, Momose M, Kato Y, Yoshie H, Burns DM (2001) Enamel matrix derivative (EMDOGAIN) rapidly stimulates phosphorylation of the MAP kinase family and nuclear accumulation of smad2 in both oral epithelial and fibroblastic human cells. J Periodontal Res 36:367-76

24. Kawase T, Okuda K, Yoshie H, Burns DM (2002) Anti-TGF-beta antibody blocks enamel matrix derivative-induced upregulation of p21WAF1/cip1 and prevents its inhibition of human oral epithelial cell proliferation. J Periodontal Res 37:255-62

25. Pierschbacher MD, Ruoslahti E (1983) Cell attachment activity of fibronectin can be duplicated by small synthetic fragments of the molecule. Nature 309:30-33

26. Wittmer CR, Phelps JA, Saltzman WM, Van Tassel PR (2007) Fibronectin terminated multilayer films: protein adsorption and cell attachment studies. Biomaterials 28:851-860

27. Morgan MR, Humphries MJ, Bass MD (2007) Synergistic control of cell adhesion by integrins and syndecans. Nat Rev Mol Cell Biol 8:957-969

28. Arnaout MA, Goodman SL, Xiong J-P (2007) Structure and mechanics of integrin-based cell adhesion. Curr Opin Cell Biol 19: 495-507

29. Suzuki N, Ohyama M, Maeno M, Ito K, Otsuka K (2001) Attachment of human periodontal ligament cells to enamel matrix-derived protein is mediated via interaction between BSP-like molecules and integrin $\alpha \mathrm{v} \beta 3$. J Periodontol 72: $1520-1526$ 